\title{
SPINAL CORD INJURIES: MALE INFERTILITY ASPECTS
}

\author{
By A. David, M.D., A. Ohry, M.D., and R. Rozin, M.D.
}

Laboratory of Physiology; Department of Obstetrics and Gynecology and The Ludwig Guttmann Spinal Cord Injury Center, The Sheba Medical Center Tel-Hashomer, Tel-Aviv University, Sackler School of Medicine, Tel-Aviv, Israel

Abstract. Among 16 married male paraplegic patients, eight had spontaneous erections and three ejaculations. Rectal electroejaculation gave poor results. Although hormonal and sperm metabolic values were normal, sperm analysis showed severe disturbances.

Key words: Spinal cord injuries; Infertility; Sperm collection.

\section{Introduction}

THE pathophysiology of the reproductive process in vertebrate animals and in man has been the subject of experimental research and clinical follow-up for many years (Bernhart, I97I; Thorburn, I922). Patients with spinal cord injuries present complicated medical as well as psychological problems. Changes in sex life and anxiety about fertility are major factors determining the course of their rehabilitation (David et al., 1976).

In injuries of the spinal cord, sexual function is affected more frequently than either micturation or defecation (Bors, 1957). Erection is preserved more frequently in high spinal cord injuries, and ejaculation usually persists in lower spinal cord injuries. Moreover, in cases of incomplete injury there is little change most of the time in the sexual function. In short, following a spinal cord injury it is not clear whether the patient will be able to perform the sex act and gain sexual satisfaction. Nor has it been scientifically established whether, even when ejaculation occurs, the emission of sperm is of sufficiently high quantity and quality to effect fertilisation.

This constitutes the subject of the present study.

\section{Materials and Methods}

Sixteen male patients with traumatic spinal cord injury, ranging in age from I 8 to 33 years old, were examined. They were assigned into three groups according to the location of the lesion: cervical group from $\mathrm{C}_{5}$ to $\mathrm{C}_{7}$ (six patients), high dorsal group from $\mathrm{D}_{3}$ to D8 (eight patients) and low dorsal group from Di 2 to LI (two patients). In the cervical group two had an incomplete lesion and four had a complete lesion; in the high dorsal group only one was incomplete while seven were complete; and both patients in the low dorsal group had a complete lesion. All I6 had neurogenic bladders and had to use a 'urinal' without indwelling catheter. None showed any signs of inflammation or infection of the testis, epididymis or prostate. All the patients had married following their injury.

Erection was present in eight cases, defined as an erection of sufficient duration to allow the spouse to perform the sex act. This occurred in the three incomplete upper motor neuron lesion cases, and in five others-three in the high dorsal

Address for reprints: Dr A. David, Head of Department of Obstetrics and Gynecology, Carmel Hospital, Haifa, Israel. 


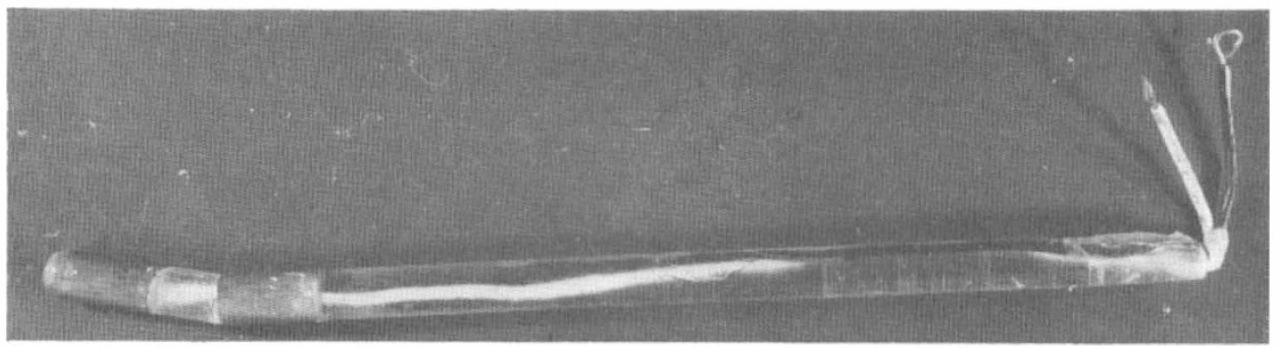

FIG. I

group and two in the cervical group. Erections occurred infrequently and were not always fully sustained. No erection was reported in the eight remaining cases.

Ejaculation occurred in only four of the upper motor neuron lesion patients, of which three were incomplete and one was high dorsal. The ejaculation occurred after prolonged masturbation and produced a slight emission of semen.

Following the clinical trials by Weisbroth (Weisbroth \& Young, I965), Dees (1965) and Kottke (Kottke \& Bensman, I974), we performed rectal electroejaculation in order to stimulate the vesical seminales and the vas deferens. A bipolar electrode was designed and made of a special polymere, Polymethylmetacrylate or Perspex, measuring $25 \mathrm{~cm}$. One tip was curved at a $150^{\circ}$ angle and outfitted with two $2 \times 3 \mathrm{~cm}$ copper plates (Fig. I), which were connected to a Grass stimulator. The contact area of $6 \mathrm{~cm}^{2}$ was large enough so the rectal mucosa sustained no burn injury (Walsh, 1975).

The Grass stimulator was set to deliver a stimulus of 4-8 msec at I 5-30 volts, with a frequency of 140 impulses/sec, and an impulse delay of $2 \mathrm{msec}$. The electrode was gently introduced into the rectum of the patient following a bowel movement and bladder catheterisation. The urine was analysed following centrifugation for possible presence of sperm. The electrode was pushed above the area. of the prostate and, during the passage of the current, gently moved from side to side in order to reach the vesical seminales. If ejaculation did not occur within I-2 min, the following changes were made in successive order: (I) voltage was increased; (2) polarity was reversed; (3) impulse duration was increased. The voltage control was advanced 2 volts every i $5 \mathrm{sec}$ until 60 volts were being discharged. After 5-IO min, the mode switch was turned off and the patient allowed to rest $15-20 \mathrm{~min}$ before the entire procedure was repeated. In all cases where ejaculation did not occur a bladder catheterisation was done following the procedure. Rectoscopy was performed in three cases and stools were examined for presence of blood.

In the cases of ejaculation sperm analysis were performed, including sperm count, motility, morphological examination, eosin test, colorimetric method for fructose, inositol and acid phosphatase. Carnitine values were assessed by gas chromatography. Radioimmunoassay techniques were used to determine FSH and LH levels, as well as plasma testosterone values, in all patients.

\section{Results and Comments}

The neurological aspects of ejaculation are still not clearly defined, although it is known that the quick passage of sperm into the prostatic urethra is under sympathetic control, and results from peristaltic movement of the vas deferens and contractions of the vesical seminales. Afferent impulses are received from the 
membranous and prostatic urethra through the parasympathetic system to $\mathrm{S}_{2}-3-4$, and back to the ischio and bulbo cavernous muscles via the pudendal nerve with secondary closure of the primary urinary sphincter of the urethra. This muscular action prevents retrograde ejaculation into the bladder. These two phases of ejaculation must be properly timed and in sequence, requiring a good adjustment between the sacral and thoraco-lumbar segments of the spine. This is, of course, a great oversimplification and does not take into consideration other possible pathways or the importance of psychogenic influence on this function.

In our patients ejaculation occurred only in four of the six patients with upper motor neuron lesion, of which three were incomplete lesions and one had a high dorsal lesion. These ejaculations did not take place as propelled ejections, but more as emanations of the semen from the external urethral meatus on the glans without propulsion. The low number of ejaculations resulting from the electroejaculation may be due to our overcaution in stimulating so as not to injure the rectal mucosa.

As mentioned previously, erection was defined as sustained erection allowing the spouse to perform coitus. This probably accounts for the low percentage of erection in our patients ( 50 per cent) as compared with 80 per cent reported by Bors (1963). However, during the electroejaculation trials we achieved 100 per cent erection.

Sperm analysis, summarised in Table I, showed that the number of spermatozoa per $\mathrm{ml}$ varied from $0.5 \times 10^{6}$ to $24 \times 10^{6}$, and the percentage of motility varied from I per cent to 60 per cent. The morphological investigation showed a high percentage of abnormal cells, from 27 per cent to 93 per cent, with a large number of amorphous spermatozoa, and tapering and pyriform spermatozoa. Bicephalic, kink and premature cells were found in a lower percentage. Fructose values ranged from $666 \mu \mathrm{g} / \mathrm{ml}$ to $3332 \mu \mathrm{g} / \mathrm{ml}$, this high value being in the normal range. Inositol level was found to be normal, $500 \mu \mathrm{g} / \mathrm{ml}$. Acid phosphatase was also in the normal range, from 566 i.u. $/ \mathrm{ml}$ to 1080 i.u. $/ \mathrm{ml}$. The only impaired value was that of the carnitine: $129 \mu \mathrm{g} / \mathrm{ml}$ instead of $250 \mu \mathrm{g} / \mathrm{ml}$ or higher. Carnitine is a good indicator of epididymal function and may play a significant role in the maturation process. It was found (Frenkel et al., I974) that carnitine level is decreased in vasectomised patients where the epididymal secretion cannot enter the seminal fluid.

Testosterone and gonadotropins were in the normal range: testosterone 3 to $8 \mathrm{ng} / \mathrm{ml}$; FSH 2 to $4 \mathrm{mIu} / \mathrm{ml}$; and LH I to $5 \mathrm{mIu} / \mathrm{ml}$. These hormone values, being in the normal range, do not give the pathogenesis of the high percentage of severe oligoasthenospermia. Yet, testicular biopsy revealed a common pathology in all the spine injuries, namely a significant decrease in spermatogenesis (Kottke \& Bensman, 1974). Our findings do not demonstrate a correlation between the

\section{TABLE I}

Sperm analysis in the paraplegic patient

\begin{tabular}{|c|c|c|c|}
\hline $\begin{array}{l}\text { Volume }(\mathrm{ml}) \\
0 \cdot 9-3 \cdot 0\end{array}$ & $\begin{array}{l}\text { Number } \\
0.5-24 \times 10^{6}\end{array}$ & $\begin{array}{l}\text { Motility } \\
\mathrm{I}-60 \%\end{array}$ & $\begin{array}{l}\text { Abnormal cells } \\
27-93 \%\end{array}$ \\
\hline Fructose $(\mu \mathrm{g} / \mathrm{ml})$ & Inositol & Acid phosphatase & Carnitine \\
\hline $\begin{array}{l}666-3332 \\
(\mathrm{Nl}=1000-5000)\end{array}$ & $\begin{array}{l}500 \mu \mathrm{g} / \mathrm{ml} \\
(\mathrm{Nl}=500 \mu \mathrm{g} / \mathrm{ml})\end{array}$ & $\begin{array}{l}566-\mathrm{I} 080 \text { i.u. } / \mathrm{ml} . \\
(\mathrm{Nl}=500-\mathrm{I} 500 \text { i.u. } / \mathrm{ml})\end{array}$ & $\begin{array}{l}\mathrm{I} 29 \mu \mathrm{g} / \mathrm{ml} \\
(\mathrm{Nl}=250-400)\end{array}$ \\
\hline
\end{tabular}


level of the cord injury and the abnormal cells. Infection may be the cause of abnormal sperm, but again our cases showed no signs of acute infection of the genitals, although one cannot exclude chronic epididymitis or prostatitis. The fact that most abnormal cells were either amorphous or tapering cells is puzzling; these morphological findings are similar to those found in varicocele, although no varicocele was palpate in any of the cases. The fact that one of the wives became pregnant following artificial insemination by sperm collected from the husband indicates that the sperm is metabolically active and capable of fertilising. All of the metabolic substrates and enzymes investigated, except for the carnitine, showed normal values.

The results of this study indicate that viable sperm are produced in the spinal injured patient. However, efforts must be made in a few directions: the technique of electroejaculation must be refined to maintain sperm collection without harm to the patient; collected sperm found to be viable should be used for artificial insemination; methods of preserving the sperm must be developed further. We are presently investigating means of deep freezing sperm collected as soon as possible following the injury, when normal spermatogenesis and spermiogenesis still occur.

\section{SUMMARY}

In a study of 16 married paraplegic patients, it was found that without electrostimulations, erections occurred in eight patients and ejaculation in three of them. Rectal electroejaculation performed in all the patients for the purpose of collecting sperm showed poor results. Sperm analysis revealed severe disturbances in spermatogenesis and spermiogenesis, the etiology of which was not clear since hormonal and sperm metabolic substrates were found to be in the normal range.

\section{RÉSUMÉ}

Dans une étude portant sur I6 paraplégiques mariés, il a été constaté que, sans électroéjaculation, des érections ont eu lieu chez 8 malades et des éjaculations chez 3 d'entre eux. L'électroéjaculation rectale, pratiquée chez tous les malades dans le but de recueillir du sperme n'a donné que de médiocres résultats. L'analyse du sperme a révélé de graves troubles de la spermatogenèse et de la spermiogenèse dont l'étiologie n'est pas claire étant donné que les valeurs hormonales et les produits métaboliques de base du liquide séminal étaient normaux.

\section{ZUSAMMENFASSUNG}

In einer Gruppe von I6 verheirateten Paraplegiken wurde ohne Elektroejakulation Erektion bei 8 Patienten und Ejakulation bei 3 von ihnen festgestellt. Die rektale Elektroejakulation die bei allen Patienten zwecks der Sameneinsammlung durchgeführt wurde, brachte schlechte Ergebnisse. Untersuchung des Samens zeigte schwere Störungen der Samenerzeugung und der Sameneigenschaften, deren Etiologie unklar bleibt, nachdem die Hormonwerte und die metabolischen Grundprodukte der Samenflüssigkeit normal waren.

\section{REFERENCES}

Bernhart (I97I). Quoted by Guttmann, L. \& Walsh, J. J. Paraplegia 9, 39.

Bors, E. (I957). Urol. Surv. 7, I77.

Bors, E. (1963). In Spinal Injuries, p. 70, ed. P. Harris. Royal College of Surgeons of Edinburgh.

David, A., Gur, S. \& Rozin, R. (1976). Arch. Med. Rehabilit. (submitted).

DEEs, J. E. (1965). Invest. Urol. 2, 539.

Frenkel, G., Petterson, R. N., Davies, J. E. \& Freund, M. (1974). Fertil. Steril. 25, 84.

Kottke, F. J. \& Bensman, A. (1974). Arch. Phys. Med. Rehabil. 55, 436.

THORBURN, W. (1922). Official History of Great War (Med. Serv.), 200, I I8.

WALSH, J. J. (I975). Personal communication.

Weisbroth, S. \& Young, F. A. (1965). Fertil. Steril. 16, 229. 